\title{
RELIGIOUS ADVERTISING AS AN EVOLUTIONARY FORM OF CANONICAL TEXT RETELLING
}

\begin{abstract}
Religious advertising is a new phenomenon within the Ukrainian media sphere. It is successfully developing within the framework of modern media technologies. The expansion of the semantic field of religious concepts, the citation of sacred texts, the synchronization of the visual-figurative series, the synchronization of the substitute characteristics of God were revealed in Ukrainian religious advertising. In traditional approaches, the substitutional function is realized mainly by anthropic visualizations and appeal to the Sacred text. Another substitutional type can be observed when the emphasis is on the verbalized story, rather than on the visual component. Characteristics of God's linguistic personality, behavioural models of God, status-role structure of interaction with God are modern substitutes of God. As a rule, the substitution is represented as a complex of the sensor experience verbalizators of the concept 'OWN'. This type of substitution causes the comfortable feelings of high selfesteem, relaxation, security, care, associated with God as the subjective source of these states. As a result, a renewal of the subjective perceptual model of communication with God is achieved. The social perception of God, through the objectification of His virtual presence in informal interpersonal interaction, including sexual, domestic, cognitive, etc., is also enriched. On account of this, the level of tolerance in society to various manifestations of deviations from traditional normative ideas (religious, ethnocultural, gender, etc.) is growing.
\end{abstract}

Keywords: religious advertising; Ukrainian media sphere; substitutional type; God's linguistic personality; communicative dynamism

* Institute of philology, National University of Kyiv; Ukraine. 
It is not an exaggeration to say that the number of scientific studies into advertising is enormous. Advertising does not only impact our ideas about the world, but also functions as an ideological construct, as a code that reflects values of the society where it appears. Moreover, advertising forms its own value system, offers behavioural models, regulates the public opinion as well as influences moral and aesthetic stances. This is all common knowledge that goes without saying. Yet, none of these facts about advertising is exhaustive and ultimate. Advertising discourse is a kaleidoscope of fast-changing communicative, cultural and social events. It is these features that mark the emerging religious advertising in Ukraine.

Religious advertising is found in many countries, but its emergence in Ukraine was rather unexpected. Ukraine is known as a country with a long atheist past. It is atheist ideology that shaped Ukrainians' worldview throughout the 70-year-long Soviet period.

After Ukraine declared its independence, people of different faiths could again attend their places of worship, carry out ritual services, get religious education, share their existential experience of communication with God and so on. One of the obvious results of the new social reality was emerging religious media, electronic media in particular. There is no doubt that innovations introduced into communication between religious institutions and people have brought in some new blood into religious communication. However, these new social circumstances have not generated a renaissance of Ukrainian religiosity.

Here is a bit of statistics. Ukrainians are predominantly Christians. According to the Religious Freedom Institute's 2020 report, 97\% of all Ukraine's religious organizations are Christian; among them, 62\% are Orthodox, 10\% are Catholic and $9 \%$ are "Just Christians" (Osoblyvosti 4).

Nevertheless, religious consciousness of Ukrainians usually lacks an affiliation to any denomination and trust in religious institutions is low. The percentage of those who consider themselves believers varies around $70 \%$ (Osoblyvosti 3). Meanwhile, 65\% of respondents (in 2000, it was 64\%) think that one may be just a believer without belonging to any definite faith (Osoblyvosti $4)$.

Ukrainians are highly tolerant to representatives of all religious denominations, while Ukrainians' religious worldview is marked with eclecticism of dogmas. At the same time, Ukrainians acknowledge the significant 
role of a religion in human life. It is an important part of cultural and spiritual heritage of an ethnic group. Yet, Ukrainians are rather passive about following rituals, various forms of services and donations to the church (Osoblyvosti 5). These features of Ukrainians as a target audience point out that they do not expect and are not well-prepared for effective religious communication.

The new circumstances have also highlighted other challenges that influence religious communication. Discourse analysts reached the following conclusion about Ukrainian Orthodox churches: they are characterized by believers' 'out-of-church' status, by the tendency to develop subcultures, by isolation of parishes, by their believers' passivity in the everyday life of their religious community. Typical features are also the differentiation of the Orthodox Church, inertia in modernization, the institutional rift, the competition among churches for the dominance in the religious sphere (Boreyko 397).

It should be noted that, in the post-Soviet time, a similar situation has been observed in the neighbouring states, namely Russia, Belarus, Moldova and so on. These territories, however, have started to show dialogical communication between the Church and the society. Religious media have begun positioning themselves interactively on the internet, yet these countries have not seen anything like the Ukrainian religious advertising of mass media products. Therefore, when Ukraine, all of a sudden, got covered with billboards of religious advertisements, it came as a real culture shock.

Unfortunately, scholars pay insufficient attention to hybrid types of influence in modern religious communication and its innovative genres in particular. From my point of view, religious advertising is an important factor to stratify values that, on the one hand, shape one's spiritual life and, on the other hand, are used through mass media as means of influence in the modern society and of setting up new standards of understanding the functionality of religious messages.

We can view religious advertising as a media practice that transforms a religious message from an archaic language into a modern one, so that the recipient may perceive it as a personal experience of communion with God. This is a new type of the dialogue between the Church and society in the post-Soviet era.

\section{Methodology}

To study this phenomenon, I chose Fairclough's methodology whose 
Discourse Analysis embraces three dimensions: 1) oral or written text, 2) discursive practice that embraces text production and text interpretation and 3) social practice (Fairclough 38). This model is complemented and developed further in works by Kress and van Leeuwen. These scientists theorize that visual images are arranged in compliance with grammar and and have rules of their own. They claim that both language and visual communication activate the same fundamental and far-reaching systems of meanings that make up our culture, but each of them does this independently and uses its own means (Kress). This methodological combination of approaches makes it possible to analyse a multimodal text that integrates visual and verbal components.

\section{The dynamics of the communicative code in religious advertising}

It is noteworthy that, at the initial stage (that is, at the turn of the $20^{\text {th }}$ century), religious advertising functioned as an ordinary information platform: it announced parishes' initiatives and religious events. It was of minimal cultural value. Since 2019, the functions of religious advertising have changed drastically: it has turned into the main channel to spread the idea of the independent Ukrainian state at its new stage and infuse it with new blood.

This became a significant event of political life, because for 20 years Ukrainians had been waiting for this change, promised by the new political order. Also, it added to religious advertising a new cultural and ideological value. Religious advertising has been used to activate social energy at this stage in the development of statehood.

According to Katrin Wanner, Orthodoxy in Ukraine functions as ambient faith:

Ambient faith is valuable to statecraft and governance precisely because of the affective experiences faith offers that can fundamentally shape political judgment and reason. It is capable of existing alongside secularism and atheism because it does not appeal to transcendent truths, other than reality of its own enduring existence, nor does it require institutional affirmation, although it benefits from it (Wanner, Fraternal 433).

Religious advertising expansively filled in Ukraine's information space. In advertising of this type, the semantic field of concept $\mathrm{CHURCH}$ was expanded 
by introducing new antagonistic pairs of verbalizers and moving them into the core zone of the concept. For example, "Army, Language, Faith!", "The church is our civilization right!", “The tomos is our historical choice!", "We are Ukraine. The Army defends our land. The language defends our heart. The Religion defends our soul. Petro Poroshenko".

Undoubtedly, as a result of the convergence of religious and political ideologies, new moral and ethical choices have arisen for the Ukrainians. The hybrid political-religious advertising was financed by Ukraine's then president within the framework of his election campaign and was, in fact, propagandist advertising. Yet, this paved a path for religious advertising as such, since there is no advertising without funding. Its cultural value, however, was determined by absolutely different factors.

Alongside the political choice, Ukrainians had to answer the following questions: 'Where is God in Ukraine? Whom does He support? Who among the leaders of Ukrainian Churches hears His voice better and brings the truth to people? What language is to be spoken in church? Should the Bible translated into modern Ukrainian remain a ritual text? What language should be used in confession, prayer and repentance? Which of the churches is the house of God Kyiv Patriarchate or Moscow Patriarchate, Ukrainian Orthodox Church or Russian Orthodox Church, or perhaps Greek Catholic Church?' and others.

Massive religious advertising has erased Soviet atheism from Ukrainians' social consciousness and made people reconsider their personal relations with God. In this sense, religious advertising as a mass media phenomenon has proved its cultural uniqueness.

The stylistic palette used in texts of religious advertising demonstrates that religious banner advertising in Ukraine has managed to overcome the limitations of political contexts. It has not turned into a propaganda resource of 'political religion', 'nationalist religion' or 'civil religion' (Kormina 131), that are located in the functional grey zone compared to the world religions. Instead, Ukrainian religious advertising is an epitome of the communicative dynamics, peculiar to the modern stage in Christian religious discourse. One of the crucial challenges that this advertising has succeeded in resolving is modernization of communicative codes used to transmit, receive and store the communicative experience with God. As a rule, this communicative experience of existential contact is systemically determined as transfer of the sacred doctrine. It presupposes religious conventions, which makes representatives of some 
denominations dance and sing at the moment of revelation, while others lose their ability to speak, they stand on their knees, prostrate themselves in awe.

The cultural value of religious advertising is determined by the media practice of updating markers of substitution of the sacred locus.

\section{Visual synchronization in advertising}

If we compare Ukrainian and international experience of advertising within religious discourse, we cannot but notice that the visual in Ukrainian religious advertising is rather poor, which is compensated for with the semantic accent placed on a verbalized narrative. As a result, it is out of question to consider religious advertising as art.

Foreign advertising quite often makes use of various anthropic images of God. For example, God may be visualized as a sportsman who takes the heaviest burden and wins; God may be depicted as a child assigned with a mission to save the world; God may appear as a rock-star, a fans' idol; God-the-Maker may come out as a PC user, etc. The perceptual model of God is based on the visual image associated with profane ideas about God. Meanwhile, the nature of communicative situations involving God is synchronized with reality through the visualizing of temporal features: objects of everyday life, pieces of clothes, interior design, associative hints at gender contexts and so on. These are the ways to modernize communicative codes used by religious institutions in their communication with believers. This approach is hardly ever found in Ukraine.

\section{Some types of verbal synchronization}

Instead, Ukrainian religious advertising correlates with a different culture, the one that appeals to the sacred locus. A Belorussian researcher into religious communication, the author of Language and Religion, N. B. Mechkovskaya argues that cultures formed by the Scripture, secular literature, school, the entire literary culture originate from church bookishness and, hence, they inherit some features typical of religious communication (Mechkovskaya 229-30). Within this approach, there has appeared a culture of quoting sacred texts. It is essentially based on rhetorical and graphic archaic forms, semantic accuracy, stylistic solemnity, reverence for authority, instructiveness, reflexivity, etc. In general, any reference to the sacred primary source imbues a text with a peculiar powerful meaning, with performativity.

The approach has been applied to some religious advertising texts that 
have acquired the function of a 'pocket Bible'. Billboards with quotes from the sacred text, put up along city highways or in crowded public places are the messages that, alongside information from coffee shops, gas stations, car maintenance services or holiday resorts sneak into people's everyday consciousness, yet they do this at different levels of the operative control.

The advertising texts "If we love each other, God dwells in us", "A stingy man hastens after wealth and does not know that poverty awaits him", "In all thy works remember thy last end" (Na Okrugnoj) and so on are the voice of the sacred knowledge that breaks through today's information noise.

A great number of both Ukrainian and foreign researchers think that in multicultural societies, in mass media information space, the traditional function of religious institutions to regulate people's behaviour is being weakened and sacred values are being secularized. As a result, advertising, with its mass media orientation and stereotype logic does not really correlate with the spiritual greatness of sacred texts. Yet, the current abundance of available information generates a social need for new diverse and easy-to-handle ways of its processing, storing and transferring. Under the circumstances, multiple semantic layers of sacred texts, biblical texts in particular, have unexpectedly proved handy for postmodern advertising constructs. It was Philo of Alexandria who pointed out the multiplicity of layers. He encouraged developing the multiplicity in works by many Fathers of the Church as an assumption of the triple nature of the Holy Scripture. Later, these ideas were taken up by philosophers, in particular, by Pavel Florensky, and got methodologically embraced in some cultures, for example, Pshat and Drash in the rabbinic tradition.

This approach is supported by modern researchers who study the origins of ethnic cultures. Thus, Macedonian scientist Mojsieva-Gusheva believes that

the multiplicity of meanings (literal, symbolic, occult-esoteric, prophetic, etc.) brings together the Bible and the postmodern pluralist worldview, as well as objectifies a new potential of cultural appeal to its authority. (Mojsieva-Gusheva 144)

Ukrainian media confirms the fact that, while retransmitting religious ideas, mass culture has replaced systematic knowledge with a set of relevant constructs that are offered to consumers of this culture. In the context of information overloading, clip-perception and a drastic decline in book-reading, 
advertising is an instrument of de-mythologizing that introduces into everyday consciousness of the Ukrainian Orthodox believer artificially constructed stereotypes based on binary oppositions originating in the depth of folk tradition (Borejko 330). Here belong also binary oppositions of the religious picture of the world and the axiological paradigm.

Meanwhile, powerful effects of the most resonant religious advertising are generated by the postmodern rejection of traditional culture. The range of deviations may vary, but is inevitably perceptible. Hence, this advertisement contains an image of God with the iconic allusion, transparent symbolism of a ritual gesture; the textual component is a biblical paraphrase that best simplifies and facilitates understanding of the religious message.

The slogan "Jesus blesses travellers" is an allusion to Psalm 30 "Lord saves faithful people" that contains a substitution for the Father role (according to Berne).

The wall of a car maintenance service was chosen as the location to exhibit this advertisement. The perceptual model is constructed with the help of visual modality that resonates with the text. The text, in its turn, objectifies the idea of God's protection, God's blessing and care for people. The image of God the Defender, the Primary Cause organizes the religious worldview as safe and predictable.

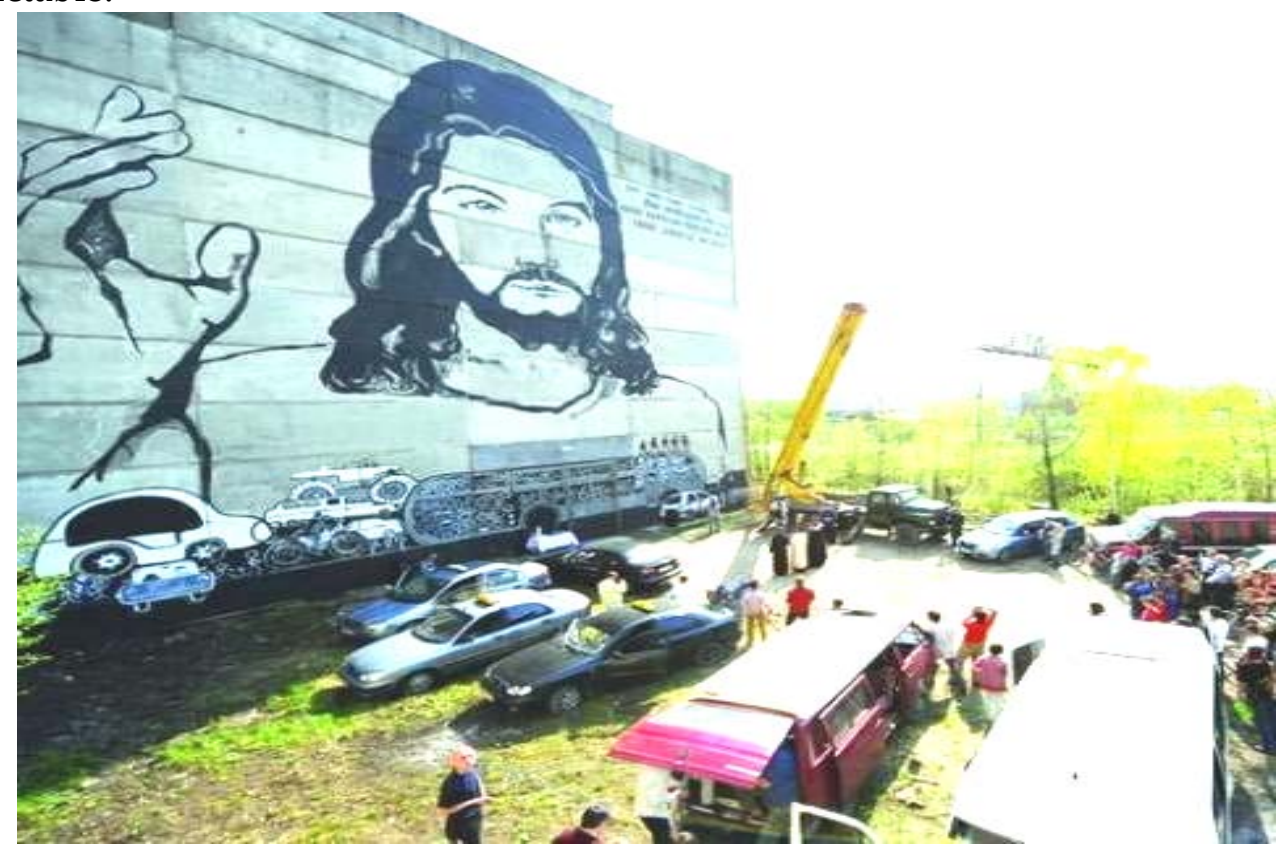


"Jesus blesses travellers"

Photo from: https://credo.pro/2011/04/44338

The implicit script of influence produced by this advertisement is activated by the substitute of the fatherly function of God, Heavenly Father, actualized within the frame of road safety. This type of substitution activates the so-called personal deficit needs. These, according to Maslow's pyramid of needs, include the need for safety. It is compensated for by the inherent tendency of advertising towards extreme simplification of real-life dilemmas.

Meanwhile, discourse analysts draw attention to the fact that peculiarities of mass media advertising may weaken not only the associative ability of appealing to sacred texts, but also the ability of symbols to evoke religious associations (Lawrych, Petrushkevich, Einstein, Watts, Dmitrieva, Shusharin). This problem has been solved in Ukrainian advertising through postmodern reconstructing of God's linguistic personality, His communicative behaviour and communicative situations he participates in.

William Alston notes that it is important to differentiate between sensor and non-sensor experience in perception. Non-sensor experience has much in common with an image that contrasts with abstract thinking in the same way sensor perception does, yet it lacks a sensor component (Alston 200).

However, the non-sensor experience may be turned into a religious narrative with the help of advertising. This substitution of God as 'Our', based on the postmodern deformation of his linguistic personality does not agree with the canonical assumptions, but it does agree with FAITH. Communicative effects of this advertising facilitate the transformation of the invisible into the visible through emotions and bodily experiences that arouse this process in a believer (Orsi 73-4).

Within the most ancient WE - THEY dichotomy that determines the basis of any ideology, religious ideology being no exception, in advertising, God speaks like WE do: 'I love, I love, I love! God', 'Let's meet on Sunday! God', 'Happy Birthday, my beloved!' Interestingly, when the first two texts were shown to respondents separately, they produced the opposite reactions: the respondents liked the first one and were frightened by the second. When offered together, the two texts were evaluated positively.

It should be noted that, stylistically, the two examples belong to everyday colloquial communication. In terms of their genre characteristics, the first one is a love note, the second is a friendly suggestion, while the third is a loving 
greeting used instead of the traditional Christmas greeting.

These are the so-called secondary genres (compare: a love note versus a declaration of love, a friendly suggestion versus a business proposal, etc.). The high level of stylistic intimicization contrasts with the Orthodox canon. Yet, despite the distant nature of advertising communication, substitutional features of God are objectified in the active intimicization of participants, are associated with simplicity and ordinariness of the interaction, sincerity and empathy and enhance the illusion of God's presence.

There is some ground to assume that Ukrainians' mentality matches this approach. The eclecticism of the Ukrainian religious worldview has been observed by researchers and confirmed statistically.

For example, the American anthropologist Catherine Wanner from University of Pennsylvania writes that the collage of religious practices in Ukraine and Russia is largely based on a combination of faith, doubts and disbelief mixed with the need for the feeling of belonging and,

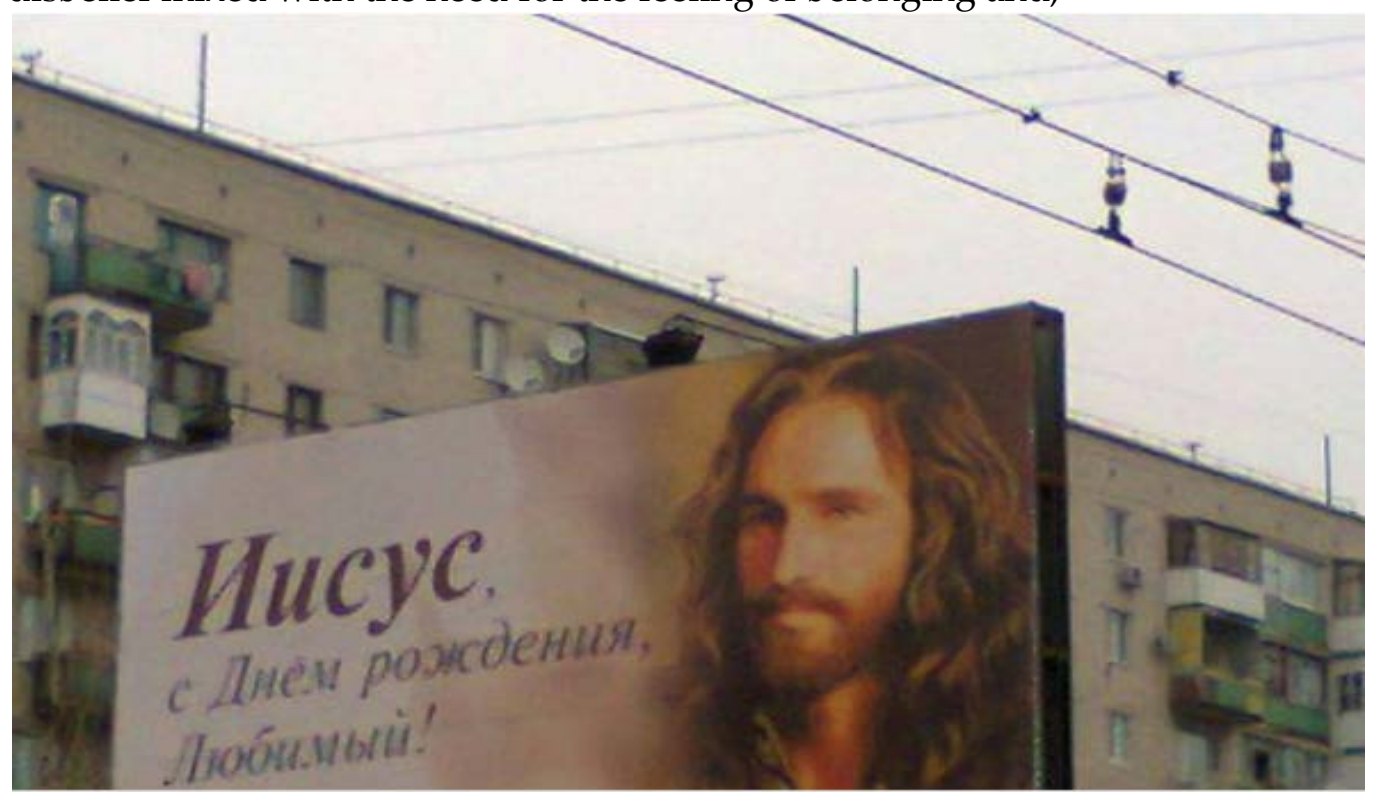

"Happy Birthday, my beloved!"

Photo from: https://vibiri.files.wordpress.com/2014/01/6.jpg

simultaneously, for avoiding any institutional inducement. She suggests calling this mixture 'syncretic secularism' since, by bringing together these, at first sight opposite, intentions and desires, religiosity creates new conceptualizations of religiosity (Forum 2). 
University of Bucharest Review $\propto$ Vol. X/2020, no. 1 (new series)

Re-writing, Re-imagining the Past (I)

The instrument of this conceptualization is, among others, God's linguistic personality that is implicitly modelled through such features as close, loving, safe, 'ridnyi', cooperative, outgoing, accessible, friendly and other ethnically specific verbalizers of OUR concept in the Ukrainian picture of the world (Dubchak). This verbalization contradicts the traditional representation of sacred texts as a part of religious practice. At the same time, it fits in well with the eclectic religious culture of Ukrainians and updates Ukrainian religious narrative. The substitutional type can be observed in advertising, when the emphasis is on the verbalized story, rather than on the visual component. Characteristics of God's linguistic personality, behavioural models of God, status-role structure of interaction with God are modern substitutes of God. As a rule, the substitution is represented as a complex of the sensor experience verbalizators of concept OWN.

This type of substitution causes the comfortable feelings of high selfesteem, relaxation, security, care, associated with God as the subjective source of these states. As a result, a renewal of the subjective perceptual model of communication with God is achieved. The social perception of God, through the objectification of His virtual presence in informal interpersonal interaction, including sexual, domestic, cognitive, etc., is also enriched. On account of this, the level of tolerance in society to various manifestations of deviations from traditional normative ideas (religious, ethnocultural, gender, etc.) is growing. Instead, the ecumenical, cross-cultural, cross-spiritual components of the cognitive process are developing.

In addition, communicative situations of the advertisements contain context frames that are unconventional for Orthodox discourse, since they do not differentiate between the sacred and the profane loci. The role structure of the communicative situation, however, remains normative for religious communication when the subject is God, while a human participates as a silent hearer. This may also be treated as a Ukrainian marker of "syncretic secularism" (Wanner).

The opposite approach to advertising the representation of God's substitutional feature is offered by advertisements that emphasize fear of the Lord. Intensification of verbal and visual markers of fear embodies the allusion to the biblical idea of the end. People's fear reflects God's greatness. Noah's days are the last days of humanity when only those will be saved who are righteous, who put themselves into the Lord's hands. Hell will await the rest. The 
metaphor is rooted into the biblical mythology of God's anger with people's depravity. Having decided to send flood onto people, the Lord decided to tell only Noah of the forthcoming catastrophe. He provided Noah with detailed instructions as to how to build an ark and rescue himself (Novyy 790-5). Yet, it is the idea of God's wrath, rather than the idea of the rescue that the advertising focuses on.

The complexly expressive "Now is much later than you think!" delivers the intention of a hidden threat. The implied script is activated in the oppositions God-devil, the good-the evil, virtue-a sin, paradise-hell as well as through the appeal to the addressee's background knowledge about the Judge of all the earth.

Fear as God's main substitutional feature is popular in particular with the churches that have to compete for believers with the traditional denominations. Their advertising differs stylistically: they often appeal to the concept of fear and use verbalizers of critical emotional states: "If you reject Jesus and His word, you'll go to hell. Don't be late to be saved by Jesus, Jesus can heal your life" (Rovenskaia).

This type of advertising corresponds to religious radicalism, which is generally not inherent in the Ukrainian mentality.

\section{Conclusion}

Ukrainian religious advertising is developing and very diverse. Religious advertising is characterized by the dialectic of the general, inherent in all Christian confessions, and the specific, inherent in individual Christian confessions. The dynamics of expressive means in religious advertising indicate the formation of a new cognitive style in the processes of obtaining religious experience. Despite its postmodern nature, that rejects traditional appeals to the sacred primary source, religious advertising in Ukraine establishes itself as a practice of mediation between people and a higher power. Within this trend, religious narratives develop in a wide range of emotional correlations and resonate both with consensus formulas in different types of social communication and with radical positions.

Religious advertising is an evolutionary form of canonical text retelling. The cultural value of religious advertising is determined by the media practice of updating markers of substitution of the sacred locus. Religious advertising draws mainly on faith in God rather than on religious tradition. 
More importantly, this communication rests on spirituality and is a component of the Ukrainian ethnically specific picture of the world, which creates prospects for its further development in the media space of Ukraine.

The expansion of the semantic field of religious concepts, the citation of sacred texts, the synchronization of the visual-figurative series and the ethnospecific synchronization of the substitute characteristics of God were revealed in Ukrainian religious advertising.

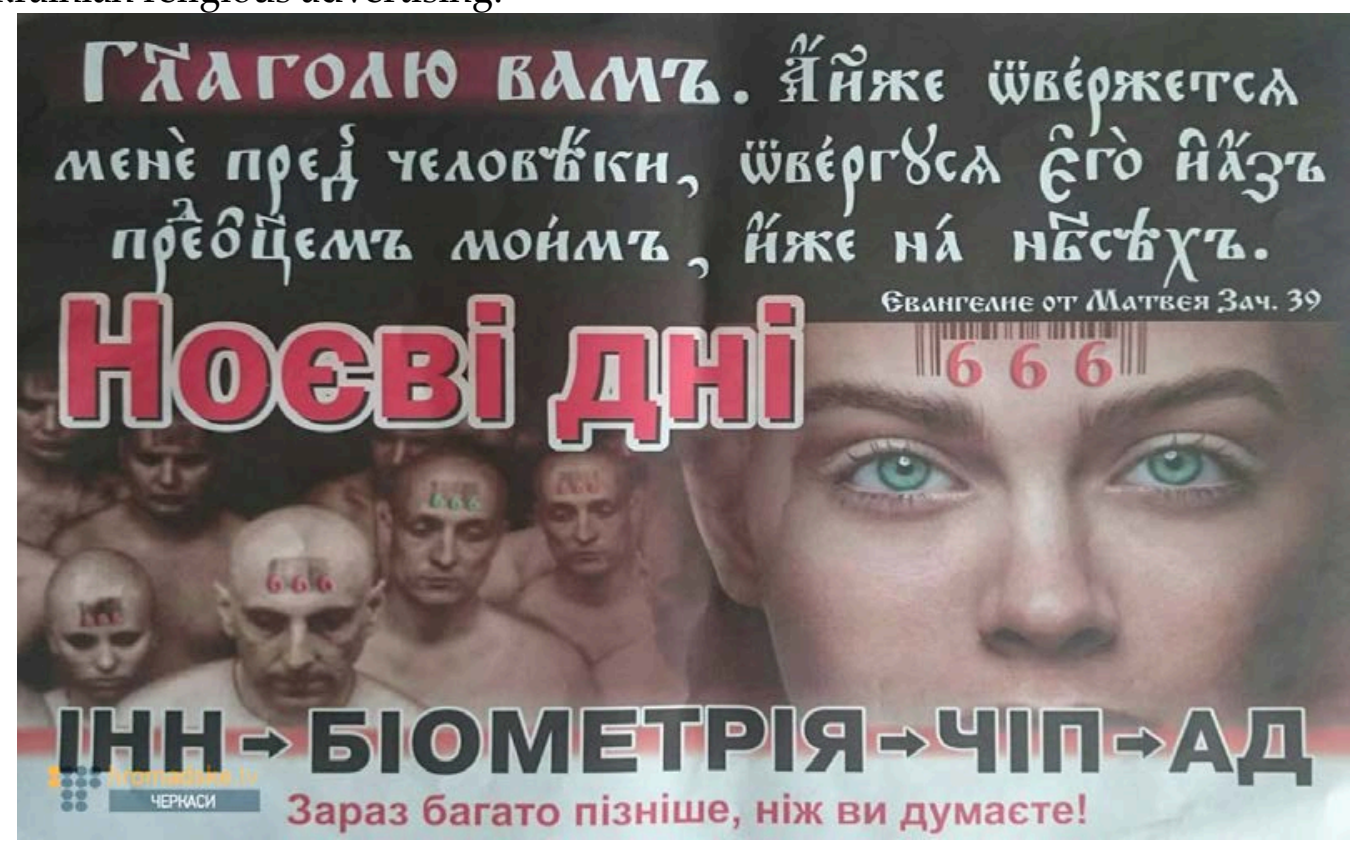

"Noah's days"

Photo from: hromadske.ck.ua

\section{Works Cited}

Boreyko, Y.H. Existence dimensions of everyday life of a Ukrainian Orthodox believer, Qualification scientific work, manuscript. Kyiv, H.S. Skovoroda Institute of Philosophy of the NAS of Ukraine, 2017: 478. https://www.filosof.com.ua

Dmitrieva, L.M. and Shusharin, S.A. Religija and branding: aspects of interaction, Omskij nauchnyj vestnik, 4 (12)/2013: 78 - 81. Print.

Dubchak, O.P. "Conceptual opposition OWN-STRANGER in the Ukrainian language model of the world", in Authoreferat, Kyiv, Dragomanov NPU, 2009. Print. 
Fairclough, N. Analysing Discourse: Textual analysis for social research. New York: Routledge, 2003.

https://www.researchgate.net/publication/31763834

Forym: Antropologia religii (2) In: Antropologicheskij forum 2017. No 35. C.: 11128. http://anthropologie. kunstkamera.ru/fi les/pdf/035/forum.pdf

Einstein, M. Brands of Faith. Marketing religion in a commercial age. Religion, Media and Culture series, ed. Stewart M. Hoover and Jolyon Mitch. Routledge, Taylor and Francis Group. (2007).

https://www.culturaldiplomacy.org/academy/pdf/research/books/nation_brandi ng/Brands_Of_Faith_-_Mara_Einstein.pdf

Elston, У. Religious experience as a perception of God, Philosophy of Religion: Almanac 2008 - 2009 / ed. V.C. Shokhin /. M: Language of Slavic cultures, 2010: 198209. Print.

Kormina, G, Panchenko A, Styrkov S. Sotsialnye issledovania religii: teoria, metody i opyt, in: Antropologicheskij forum. 2017. No 35/2017: 129-66.

http://anthropologie.kunstkamera.ru/files/pdf/035/kormina_panchenko_shtyrko v.pdf

Kress, G. Front pages: (The critical) analysis of newspaper layout / In Allan Bell and Peter Garrett (Eds.)// Approaches to Media Discourse, Oxford Blackwell, 1998: 186-219. Print.

Lawrysh, Y. The Church in the New Media of Ukraine: Problems and Priorities of Communication, Lviv, Company" Imperial", 2017: 156. Print.

Mechkovskaia, N.B. Jazyk i religija, 1998. https://stavroskrest.ru > files > books > mechkovskia

Novyy Biblejskij Slovar: Chast 2. Biblejskie realii Translation of the New Bible Dictionary, 2001. Print.

Mojsieva-Gusheva, Ja. Biblia, Makedonskij etnos i makedonskaja literature, in: "Biblia i natsionalnaia kultura", Perm, 2005: 168. Print.

Na Okrugnoj v Kieve...< http://prportal.com.ua > Факты > на-окружной-вкиеве...

Orsi, R. A. Between Heaven and Earth: The Religious Worlds People Make and the People Who Study Them. Princeton: Princeton University Press, 2006: 264. Print.

Osoblyvosti religijnogo i tserkovno-religijnogo samovyznachennya gromadyan Ukrainy: tendentsii 2000 - 2020 rr. (informatsijni materialy) Features of religious and church-religious self-determination of citizens of Ukraine: 
tendencies 2000-2020 years (information materials).

https://razumkov.org.ua/uploads/article/2020_religiya.pdf\#page=

Petrushkevych, M. Constructing religious discourse with the help of mass media, Visnyk Cherkassy University, Philosophy series, 2/2018: 53-9. Print.

Rovenskaia Tserkov “Hristos est otvet”. cnl.news. 20:55 (UTC+6), 12.11. 2020.

Ровенская церковь «Христос есть ответ» установила по городу 10 билбордов о Боге/

Wanner C. (ed.). State Secularism and Lived Religion in Russia and Ukraine. N.Y.: Oxford University Press, 2012: 304. Print.

Wanner, C. "Fraternal" nations and challenges to sovereignty in Ukraine: The politics of linguistic and religious ties. American Ethnologist, 41(3)/2014: 42739. https://doi.org/10.1111/amet.12097

Watts, F. Psychology, religion and spirituality: Concepts and applications, Cambridge University Press, 2017, 1st ed. Print. 